\title{
Managed Care and Health Care Reform: Everything Old Is New Again
}

\author{
Kathleen A. Fairman, MA, and Frederic R. Curtiss, PhD, RPh, CEBS
}

Patients are happy, doctors are happy and costs per patient are about 5 percent lower than in other states where the quality of care is often worse. ${ }^{1}$

A 1991 New York Times article reported that the "pioneering" state of Arizona, a "late starter in Medicaid," had provided a health system model for the nation in the Arizona Health Care Cost Containment System (AHCCCS). At that time, AHCCCS was the only Medicaid program in the United States in which nearly all beneficiaries were enrolled in managed care organizations (MCOs) that were reimbursed on a prepaid capitated basis. Because of a physician participation rate exceeding 50\%, remarkably high for a Medicaid program, AHCCCS had brought about truly mainstream managed care for the low-income members that it served, the article reported: "In much of the country, [Medicaid beneficiaries] would be left to seek treatment in shoddy 'Medicaid mills' or, at great public expense, in overcrowded emergency rooms. ... In Arizona, things are different."

Glowing press coverage of the program continued. In 1995, a Time Magazine article observed that AHCCCS was being "hailed as a model of managed care" because of the program's emphasis on primary and preventive care, prohibitions against "cherry picking" healthy enrollees, and use of "intensely competitive" bidding to award contracts to MCOs. ${ }^{2}$ "The most remarkable thing," Time reported, "is that the state government managed to come up with a program that makes just about everybody happy: the patients, the doctors, the bureaucrats and the number crunchers."

AHCCCS did not become the dominant national model for health care financing and delivery as predicted in the 1990s. ${ }^{3}$ But AHCCCS became the Phoenix in 2009, when it was once again described as "a proven, efficient model for national health reform," this time by an Arizona legislator who is a proponent of current health care reform proposals. ${ }^{4}$ More importantly, this cycle of events was not limited only to AHCCCS; it is a pattern that has been repeated over the past several decades in the United States. Insights into public opinion about managed care, consumer choice, and preventive medicine are critical to understanding the prospects for the structure of health care financing and delivery in the United States in the coming years.

\section{Prepaid Capitated Managed Care on the Ascent: A Model for Health Reform}

Objective evidence about AHCCCS, although mixed on a few points, generally supported national enthusiasm for the program. Research conducted by the independent evaluator for the Health Care Financing Administration (now the Centers for Medicare \& Medicaid Services [CMS]) in the 1980s and 1990s yielded find- ings suggesting that the AHCCCS model produced comparable or slightly better quality of care at a lower cost compared with traditional fee-for-service Medicaid. ${ }^{5-7}$

For example, an evaluation of medical records for children and pregnant women enrolled in Aid to Families with Dependent Children (AFDC), conducted from 1985 to 1987, found that health care for children in AHCCCS was "earlier, more frequent, and more complete" than was the care provided to children enrolled in the traditional Medicaid program in neighboring New Mexico. ${ }^{5}$ Pregnancy outcomes in Arizona and New Mexico beneficiaries did not significantly differ. ${ }^{5}$ A beneficiary survey conducted in 1985, 3 years after program implementation, found few significant differences in access to care for beneficiaries in AHCCCS versus New Mexico. ${ }^{7}$ Although preliminary because the Arizona program was relatively new, survey results suggested that AHCCCS beneficiary satisfaction rates were generally high. Of beneficiaries who rated their medical care, $88 \%$ in AHCCCS and 95\% in New Mexico said that they were either very or somewhat satisfied. Although satisfaction was slightly lower in AHCCCS than in fee-for-service arrangements on 3 of 7 service measures, evaluators described these differences as "very small." And, on satisfaction with "particular elements of medical care," AHCCCS scored "very high." Beneficiary-reported access to routine care was slightly better in AHCCCS than in traditional Medicaid, and access to emergency services was reduced-perhaps, the evaluators noted, because "emergency care is a service thought to be widely abused in Medicaid" and the program could be "appropriately keep[ing] people out of emergency rooms."

Evaluation of the Arizona Long Term Care System (ALTCS) program for the elderly and physically disabled, which was implemented in 1989 and emphasized use of home care services in lieu of nursing home placement, found "a much more coordinated system of care in Arizona" than in New Mexico. ${ }^{5}$ Several problems in the quality of nursing home care in Arizona, including a lower rate of influenza vaccine use and higher rates of pressure sores, fevers, and catheterization compared with New Mexico, were identified and addressed as a result of the evaluation; however, ALTCS and traditional Medicaid nursing home residents did not significantly differ with respect to falls, fractures, or use of psychotropic medications. ${ }^{5}$

In addition to apparent quality of care, access, and beneficiary satisfaction measures that favored the AHCCCS program, efficiency (cost) assessments were encouraging. Assessments of utilization suggested that the use of "gatekeepers" (primary care providers) who coordinated patient care was successful in reducing utilization and lowering costs. ${ }^{6,7}$ Use of 
evaluation and management services in AHCCCS was approximately equal to that of traditional Medicaid for AFDC recipients (approximately 5 visits per person-year) and higher for ALTCS enrollees than for traditional Medicaid elderly and physically disabled beneficiaries (13 vs. 9 per person year, respectively). However, AHCCCS hospitalization days per 1,000 person-years were much lower (for Arizona and traditional Medicaid, respectively: 590 vs. 976 in AFDC, 3,692 vs. 4,731 in ALTCS). ${ }^{5}$ In 1991, AHCCCS medical care expenditures were $\$ 113.20$ per month for AFDC beneficiaries and $\$ 136.68$ overall. ${ }^{6}$ After adjusting expenditures in traditional Medicaid states for per capita health care service costs and rural/urban geographic distribution, program evaluators estimated that per beneficiary per month medical costs in a traditional Medicaid program would have been $\$ 126.56$ for AFDC and \$168.44 overall, suggesting that AHCCCS had reduced expenditures by approximately $11 \%$ and 19\%, respectively. ${ }^{6}$ From 1987 to 1989,5 to 7 years after the initial startup, medical service costs in AHCCCS grew by approximately 9\%, compared with $17 \%$ in other Medicaid programs. ${ }^{1}$

These medical cost savings were partially offset by higher administrative costs, which in 1991 were approximately 12\% of medical service expenditures in AHCCCS compared with approximately $4 \%$ in traditional Medicaid. ${ }^{6}$ After accounting for medical cost savings and administrative cost offsets from 19831993, program evaluators estimated that compared with traditional Medicaid, AHCCCS's total costs were 7\% lower for acute care enrollees and 16\% lower for ALTCS enrollees. ${ }^{5}$

\section{National Trends Point to Expansion of Prepaid Capitation}

Events occurring at the national level seemed to align prospects for health care reform to a system that would closely resemble the AHCCCS prepaid capitated model. Just 3 years after the New York Times predicted in 1991 that Arizona's model would have "a central place in proposals being considered in Washington to expand Medicaid greatly" to cover America's uninsured, ${ }^{1}$ an ambitious Tennessee program was developed as what seemed like the next logical step in the application of prepaid managed care to health care reform. TennCare, launched in 1994, simultaneously moved more than 800,000 Medicaid enrollees from fee-for-service to 1 of 12 private MCOs contracted on a prepaid capitated basis, while expanding enrollment to an additional 500,000 uninsured persons who were either low-income (less than 200\% of federal poverty level) or uninsurable because of pre-existing conditions (no income limit). ${ }^{8}$ All but 1 TennCare MCO used fixed capitation to pay providers, and 6 months after program implementation, all MCOs used closed drug formularies. ${ }^{9}$ Cost-sharing requirements were low, zero for some services, and the state provided financial incentives to the MCOs "to keep enrollees healthy and to avoid the more expensive inpatient care." The financial rationale underlying TennCare was that the savings generated by managed care (e.g., prepaid capitation, volume discounts, and use of preventive care) would offset the cost of the enrollment expan- sions. Initial projections indicated that cost savings of $\$ 7.2$ billion would be accrued by the federal and state governments over the first 5 post-implementation years, salvaging the state's troubled finances. ${ }^{8,10,11}$

At about that time, Ira Magaziner, the respected health policy analyst who in 1993 became the day-to-day operating officer of then First Lady Hillary Rodham Clinton's Health Care Task Force, advocated a system of "managed competition" as the optimal strategy in a newly reformed health care structure. ${ }^{3}$ Under managed competition, systems of physicians and hospitals, termed "accountable health partnerships," would contract with purchasing cooperatives to provide benefit packages and receive fixed capitation payments. ${ }^{12}$ This system of managed competition was similar to that used by AHCCCS, in which many, although not all, MCOs consisted of privately-owned networks of physicians and hospitals (commonly called physician hospital organizations or PHOs) or hospital-owned health plans. Prepaid managed care was on its ascendency, poised to become the dominant method of financing and delivery of health care to an ever-expanding list of covered enrollees.

\section{The "Managed Care Backlash"- What Happened to Managed Competition?}

Yet, as sometimes befalls ambitious ventures that depend on a complex interaction of political networking and public opinion, events did not meet the expectations of those who believed that the role of prepaid capitated managed care in health care reform was assured. In the summer of 1994, Clinton's managed competition proposal died, not quietly, at the hands of a nervous public that "fear[ed] faceless federal bureaucrats making important medical decisions." ${ }^{3,13}$ During the subsequent 4 years, consumer fears of loss of decision-making control at the hands of their MCOs began to build. ${ }^{13,14}$ The case of Nelene Fox, a 38-year-old woman with advanced breast cancer who in 1992 had unsuccessfully sought coverage of a bone marrow transplant from her health maintenance organization (HMO), was widely publicized. Although Fox's bone marrow transplant was covered by charitable contributions 8 months prior to her death, her family won an $\$ 89$ million judgment, $\$ 77$ million of which was for punitive damages, against the HMO in December 1993. ${ }^{15}$ In a press interview following the verdict, Fox's attorney referred to the case as a "warning" to other payers. ${ }^{15}$

Objective evidence suggesting that the quality of care in HMOs was equivalent to that provided in indemnity insurance was largely ignored. ${ }^{16,17}$ When a character in the popular 1997 film, As Good as It Gets, used profanity in describing her HMO's treatment of her asthmatic son, movie audiences burst into spontaneous applause. ${ }^{16}$ By 1998, political candidates were talking about "patients' rights bills," and a total of more than 1,000 consumer protection bills had been introduced in state legislatures to allay the fears of managed care enrollees that their cost-conscious MCOs would fail to cover necessary medical treatments. ${ }^{13,14} \mathrm{~A}$ 
popular press article reported in 1999 that methods commonly used by MCOs to save money, such as "further reducing hospital stays, restricting patients' access to specialists and expensive medical tests, [and] limiting patients' choice of physicians—are ones patients are coming to hate."13 Public sentiment spilled over into the 2000 presidential election, when then candidate George W. Bush told a debate audience, "If I'm the president ... people will be able to take their HMO insurance company to court."18 The 2002 movie, John Q, in which a father holds emergency room patients and staff hostage because his insurance plan denied coverage of a heart transplant necessary to save his son's life, continued the theme. ${ }^{19}$ The managed care backlash was in full swing.

The sources of concerns about managed care were explored in a series of opinion polls reported by Blendon et al. (1998), with response rates of approximately 50\% (range 49\%-51\%), that were conducted from 1995-1997 both in national samples and in a subsample of residents of California, where managed care penetration was extensive..$^{14}$ Results suggested what Blendon et al. described as "seemingly contradictory pieces of information." First, respondents were generally, although certainly not uniformly, satisfied with their plans. Of adults younger than 65 years of age, $66 \%$ of managed care enrollees and $76 \%$ of traditional plan enrollees gave their health plan a grade of "B" or better. (Unfortunately, the remainder of the distribution, including the proportion expressing no opinion about their health plan, was not reported by Blendon et al.) However, many respondents expressed concern about managed care, with 54\% indicating that the increased use of managed care would damage health care quality in the future and only 33\% indicating that managed care would improve quality. When asked how the money saved by MCO cost-containment was used, $72 \%$ agreed that it "helps insurance companies to earn more profits," but only $49 \%$ agreed that it "makes health care more affordable for people like you." More than one-half (55\%) of managed care enrollees, but only $34 \%$ of traditional insurance enrollees, expressed the view that they were at least somewhat worried that if they were sick, their health plan would "be more concerned about saving money than about what is the best medical treatment." Notably, however, the California respondent subsample expressed views about managed care similar to those of other respondents. For example, in both the United States as a whole and the California subsample, $52 \%$ of respondents supported increased governmental regulation of managed care. ${ }^{14}$

Blendon et al. explained these findings as attributable both to consumer experiences with MCOs and to the sometimes unreliable sources of information trusted by respondents. When asked about news stories reporting events that are unusual in MCOs, a majority of respondents believed that these events were common. For example, when asked how often HMOs fail to cover a child's cancer treatment, $26 \%$ of respondents answered "often," $40 \%$ "sometime," and only 23\% "rarely." Of those respondents who reported believing that MCOs do a "bad job" serving consumers,
$21 \%$ based their opinion on personal experience, 22\% indicated that their main source of information was the media, and $32 \%$ said that their opinion was based on the views of family or friends. Blendon et al. concluded that the managed care backlash was partly driven "by relatively rare events that seem threatening and dramatic but have been experienced by few consumers personally."14 Nonetheless, it was clear by 1998 that perceptionwhether accurate or not-had become reality.

Meanwhile, TennCare, the once-vaunted example of what was to be a reformed universal coverage system undergirded by effective care management, was in "significant jeopardy"20 by 2002 partly because of similar consumer concerns, according to analysts. ${ }^{8,9}$ Although even basic factual information about TennCare is controversial, ${ }^{21,22}$ it is clear that the program's promised rescue of the state's budget shortfall never materialized, partly because lack of managed care penetration in the Tennessee marketplace in the early 1990s produced MCOs that were not equipped to manage a large influx of low-income enrollees in 1994, 8,20,23 and partly because extensive litigation filed by advocates seeking to expand covered benefits "significantly limited the ability of MCOs to effectively [manage] care" according to analysts. ${ }^{8,9}$ In the first 9 months of 1997, MCOs contracted with TennCare lost more than $\$ 20$ million, and in 2001, the total TennCare shortfall was estimated at $\$ 342$ million. ${ }^{9}$ In July 2002, the state scuttled prepaid capitation altogether, and began paying TennCare MCOs as administrative service organizations (ASOs) responsible for claims processing and case management, with all health care service costs passed through to the state. ${ }^{8,9}$ One year later, the responsibility for managing pharmacy costs was also removed from participating MCOs, and pharmacy claims processing was turned over to a pharmacy benefits management company (PBM) under another ASO arrangement. ${ }^{8,9}$ TennCare's "managed" care had reverted to a largely fee-for-service model.

\section{Prepaid Managed Care Is "New" Again}

By 2009, the pendulum that had swung away from capitation in the late 1990s began to swing back, with prepaid health care financing once more beginning to play a prominent role in health reform proposals. A February 2009 Congressional Budget Office (CBO) analysis of options for expanding health insurance coverage and controlling costs in the United States suggested that "payment systems should move away from a fee-for-service design" and gravitate toward systems that could include "fixed payments per patient, bonuses based on performance, or penalties for substandard care." ${ }^{24}$

Similarly, in Massachusetts, which had implemented a universal coverage package in 2006, several factors-including higher-than-expected enrollment in the state-subsidized "Commonwealth Care" plan, average annual premium increases exceeding both initial projections and the national average, and government cost outlays that "challenge the fiscal sustainability of the program"-prompted a review of potential cost 
savings opportunities. ${ }^{25-28}$ The review was conducted by the Rand Corporation and published in August 2009. ${ }^{25}$ Among the options identified by Rand, adoption of a bundled payment method, in which insurers would be encouraged "to provide a single payment for all services related to a treatment or condition" and thereby provide "a financial incentive to reduce the volume or intensity of services" was assessed as the most promising, with an estimated potential cost savings of up to $5.9 \%$ of projected total medical expenditure from 2010 to $2020 . .^{25}$

A special Massachusetts commission tasked with addressing the state's cost overrun problem reached a similar conclusion, finding that paying providers on a fee-for-service basis "is a primary contributor to the problem of escalating costs and pervasive problems of uneven quality."29 The commission recommended replacing fee-for-service reimbursement with a "global payment system" that would go beyond bundled payment methods that are episode- or setting-based, such as diagnosis-related groups (DRGs), and "prospectively compensate providers for all or most of the care that their patients may require over a contract period, such as a month or year." Program features similar to those used by AHCCCS, including detailed oversight, health information technology, and payment adjustments to promote "provision of accessible and high quality care" were included in the proposal. ${ }^{5,25,29}$ Remarkably, a news account of the proposal indicated that the commission had urged the state to "pay for care a new way." ${ }^{30}$ The managed care backlash of just a decade before was seemingly forgotten.

\section{"If They Choose, We Lose" 31 -Conflict Between Full Choice and Universal Coverage}

Widely viewed as at least partly responsible for the demise of the Clinton health care proposal, the "Harry and Louise" advertising campaign of 1993 and 1994 featured a couple lamenting the loss of their private insurance coverage upon implementation of universal health care. ${ }^{32}$ The ad campaign, sponsored by the Health Insurance Association of America (HIAA) at a reported cost of $\$ 14$ million, ${ }^{33}$ prompted a blistering attack from Hillary Rodham Clinton against industry "greed."3 But her attack, according to political analysts, was so widely publicized that it drew even more attention to the HIAA's message. ${ }^{3}$ Following Clinton's response, the HIAA raised $\$ 30$ million in donations over its normal annual operating budget of $\$ 20$ million. ${ }^{3}$

The core theme of the ad campaign was choice. "This was covered under our old plan. ... Having choices we don't like is no choice at all," Louise says, thumbing through a stack of bills. "If they choose, we lose," the couple adds.. ${ }^{34}$ Indeed, to the American health care consumer, choice of treatment, plan, and providers has proven to be a key issue over the years, in ways and for reasons that have sometimes baffled health care decision makers and, many would argue, thwarted even the most reasonable attempts at the cost containment efforts that are essential to making universal coverage systems financially sustainable.
For example, throughout its history, TennCare has been plagued by numerous highly controversial lawsuits, most filed by advocates on behalf of enrollees, seeking coverage of denied benefits. Prominent among these was the case of Grier v. Goetz, filed by the Tennessee Justice Center (TJC) over "procedural issues relating to the termination, denial, delay or modification of TennCare services to individual enrollees." of 2000 required that all enrollees who were denied coverage of a drug not on the TennCare formulary, including any brandname drug, be provided with a 14-day supply of the drug pending appeal. ${ }^{8,9,35}$ To accommodate the consent decree, BlueCross BlueShield of Tennessee, which at that time served more than $40 \%$ of TennCare enrollees, eliminated its medical necessity review process for medical services and prescription drugs in October 2000. ${ }^{9}$ By January 2003, the Grier consent decree was generating approximately 8,000 pharmacy benefit appeals each month, and an analysis conducted by PriceWaterhouseCoopers estimated that the cost of compliance with the decree was $\$ 50$ million annually. ${ }^{9}$ In December 2003, an analysis of the program's financial viability, conducted by McKinsey and Company, "unequivocally declared that TennCare as it was then structured was not viable and, if unchecked, would threaten the fiscal health of the entire state." pharmacy budget. ${ }^{9}$

TennCare's subsequent history provides a remarkable illustration of the tradeoff between choice and access-or perhaps of lack of understanding that such a tradeoff exists, depending on whom you ask. In November 2004, Tennessee governor Phil Bredesen announced a plan to return to a traditional Medicaid program in Tennessee, citing primarily the consent decrees that had resulted from benefits litigation, which "obligate TennCare to provide extraordinary benefits well beyond federal requirements" and were the primary driver of a 26\% annual growth rate in TennCare's drug costs compared with an average growth rate of $17 \%$ in neighboring states. ${ }^{21}$ In early 2005 , the state finalized a plan to scale back enrollment and reduce benefits. The plan proposed disenrollment of 323,000 adults, limits on benefits for 396,000 adults remaining in the program, and preservation of full benefits for all 612,000 enrolled children. ${ }^{9}$ The proposed benefit cutbacks, which were approved by CMS in June 2005, included a monthly limit of 5 prescription drug claims for some adult beneficiaries, elimination of optional services including private-duty nurses for adults, and "small copayments" for some beneficiaries. ${ }^{9}$ By December 2006, adults could also access "any medications from a list of more than 400 medications that do not count against the limit."

TJC, which had been the instigator of much of the benefits litigation, challenged the cutbacks. Following a protracted legal battle that included review by the U.S. Circuit Court of Appeals, the state stopped processing new enrollment applications for several benefit categories, including individuals classified as uninsurable, in April 2005. Disenrollment and imposition of the 
prescription drug restrictions began in July 2005. ${ }^{9}$ In September 2005 , following a court ruling granting relief from some of the consent decrees, BlueCross BlueShield of Tennessee reinstated medical necessity review for some medical services. ${ }^{9}$ The state proposed additional limits, including a cap of 12 doctor visits and 20 hospital days per year, in February 2006, and MCO risk contracts were reinstated in 2007-2008.9

Today, the TJC website describes medical necessity review as "your doctor's worst nightmare" and argues that because of the cutbacks, "over 200,000 people have lost access to health care and the remaining 396,000 adults on TennCare are subject to arbitrary limits in prescriptions and services." ${ }^{22}$ TJC maintains that the consent decrees were not responsible for cost overruns but were merely a political scapegoat. ${ }^{36}$

\section{Choice Is a Key Factor in Consumer Perceptions of Insurance Coverage}

Although certainly unusual in scope and intensity, the type of conflict that took place in TennCare is not uncommon and often involves an understandable desire for unfettered choice of treatment. This viewpoint was expressed by a patient advocate in a recent Arizona newspaper column on therapeutic switching: "The insurance company feels that drug B, a cheaper option, will work just as well as drug A, prescribed by your physician. Until you experience harmful side effects such as a seizure, heart attack or worse, you are forced to take drug B. You and your personal physician have no say in the matter." ${ }^{37}$ Patients' rights bills proposed in 1998 sounded essentially the same theme, with calls for rights of patients to "appeal denials of services and benefits by a health plan to an outside body; access a specialist when needed; use doctors outside the plan (for a larger fee); ... [and] sue an employer-sponsored health plan for damages."13

Blendon et al.'s 1995-1997 consumer surveys produced similar findings; $58 \%$ of respondents indicated that their view of their health plan would be less favorable if "patients needed to get approval from the plan before they could receive expensive medical treatment," and 56\% indicated that MCO requirements that doctors "follow certain guidelines in treating patients" are "a bad thing because decisions about treatment should be entirely up to the doctor." ${ }^{\prime 4}$ As we have observed previously, the 2004 case of an elderly Arizona man who traveled to Mexico to purchase brandname Valium only to find himself imprisoned on drug charges for 2 months is instructive. The reason for his trip was that his wife believed that the generic alternatives covered by their health plan, including chemically equivalent diazepam, were ineffective. ${ }^{38}$

Choice of treatment, even treatments that are not necessarily effective or cost-effective, is tremendously important to the American health care consumer. Analyst David Gratzer writes that the "stunning consumer rebellion" against HMOs in the 1990s was a manifestation of this desire for choice. "The idea of being told what tests to get or which hospital to go to was seen as absurd and offensive ... To Americans, HMOs represented a loss of autonomy."16

\section{A "Once-in-a-Lifetime Chance" 39 -Beliefs About Prevention and Health Care Cost}

An advertising campaign launched in October 2009 touts the expected benefits of incorporating preventive medicine as a "central pillar" of health care reform. "We will continue to struggle with health care costs until we do a better job of keeping people healthier," the advertisement reads. "With an investment of $\$ 10$ per person per year in proven community-based [programs] to increase physical activity, improve nutrition, and prevent smoking and other tobacco use, the country could ... [receive] a return of $\$ 5.60$ for every $\$ 1$ invested." 39 The advertisement's returnon-investment (ROI) claim was based on a non-peer reviewed report of a literature review combined with an economic model, sponsored by the Trust for America's Health (TFAH) ${ }^{40}$ Much to the credit of the TFAH authors, the report clearly describes available research information about community-based prevention as "limited, and outcomes were not reported in a standardized way."40

Although the ROI claim and the 2009 TFAH report focus on "prevention programs that do not require medical treatment," the TFAH also advocates "an enhancement of preventive care services" as a way to "ultimately save money and lead Americans down the road to longer, healthier lives." ${ }^{.1}$ For the Medicare program, TFAH argues that "many clinical prevention services could also reduce Medicare spending. Improving disease screenings and immunizations, for example, could help people detect diseases early or avoid them altogether. This often makes treatment more effective or keeps problems from getting worse, [leading] to health care cost savings." ${ }^{41}$ Similar sentiments were expressed in a February 2009 opinion-editorial piece by Senator Max Baucus and the late Senator Edward Kennedy, who argued that under universal coverage, "health costs ... will go down as more people get the preventive care and the timely effective treatments they need." ${ }^{42}$

The belief that increased use of preventive medical services produces cost savings has emerged periodically over the past 4 decades. For example, the Rand Health Insurance Experiment (HIE) was launched during the 1970s in response to concerns expressed by the Nixon administration that patient cost sharing might be "penny wise and pound foolish" in discouraging use of preventive services that could produce savings in total medical costs. ${ }^{43} \mathrm{~A}$ politically diverse group of presidential candidates in the 2008 election, including then Senator Hillary Rodham Clinton, Senator John Edwards, and Governor Mike Huckabee, expressed similar views. ${ }^{44}$ The idea of saving money by "focus on prevention: wellness not sickness," a Clinton campaign slogan, is appealing and intuitive. However, it is also unsupported by evidence and mathematically unsound for most (although not all) preventive health care interventions, because both the number of screenings necessary to detect disease and the number of preventive treatments necessary to avoid a major adverse event (e.g., myocardial infarction, stroke) are large in all but high-risk groups. 
In a meta-analysis of 599 studies assessing cost-effectiveness ratios for health care interventions (publication dates 2000-2005), Cohen et al. (2008) found that the distribution of quality-adjusted life years (QALYs) was roughly equal for preventive measures and treatments-meaning that opportunities for cost-effective care were roughly equivalent for prevention versus treatment. ${ }^{44}$ Only about $20 \%$ of preventive measures and $18 \%$ of treatments were cost saving, and approximately 30\% of preventive measures cost $\$ 50,000$ per QALY or more. Cost per QALY was $\$ 250,000$ or more for $9 \%$ of preventive measures. Cohen et al. concluded that some preventive measures, such as Haemophilus influenzae type b vaccination of toddlers, save money; however, "broad generalizations" of cost savings from prevention "can be misleading" and were generally overstated by political candidates. ${ }^{44}$

Kahn et al. (2008) reached similar conclusions in an analysis of National Health and Nutrition Education Survey IV (NHANES) data, first identifying the proportions of U.S. adults who are candidates for interventions, then using statistical modeling applied to clinical trial data to simulate treatment effects on costs and outcomes for 11 recommended health care interventions. ${ }^{45}$ Kahn et al. found that an astonishingly high $78 \%$ of U.S. adults, approximately 156 million in 2008, were candidates for recommended prevention activities including smoking cessation (49.3 million), weight reduction in adults with body mass index greater than 30 kilograms per squared meter ( $\mathrm{kg} / \mathrm{m}^{2}, 60.3$ million), lowering lowdensity lipoprotein cholesterol (LDL-C) in low-risk individuals (15.4 million), lowering LDL-C in high-risk individuals (17.9 million), lowering blood pressure in nondiabetic individuals (30.8 million), and lowering blood pressure and LDL-C in diabetic individuals (11.5 million and 13.0 million, respectively). ${ }^{45}$

Assuming 1 office visit per year and use of smoking cessation medications, Kahn et al. found that prompting Americans to quit smoking was a cost-saving measure over a 30-year time horizon. However, smoking cessation was the only intervention that saved money. Assuming 100\% compliance, applying all interventions simultaneously would add approximately 244 million QALYs at a cost of approximately $\$ 8.5$ trillion over a 30 -year time horizon. The cost offset for avoided medical events would be approximately $\$ 904$ billion, and total net cost would be increased by $\$ 7.6$ trillion. The primary reason for the expenditure increase was the large number of people treated to avoid 1 event, especially in low-risk subgroups. For example, Kahn et al. estimated that treating 15.4 million low-risk individuals to lower LDL-C at an estimated annual cost of $\$ 1,281$ (1 annual visit at $\$ 74,1$ year of branded statin at $\$ 1,082$, laboratory testing at $\$ 125$ ) would cost a total of approximately $\$ 736$ billion (after discounting) to prevent 924,000 myocardial infarctions and 553,000 strokes over 30 years, for a cost per QALY of $\$ 272,061$. Blood pressure reduction in 30.8 million nondiabetic individuals, at an annual cost of $\$ 1,582$, would cost approximately $\$ 2$ trillion to avoid 2.9 million myocardial infarctions and 4.6 million strokes, for a cost of \$52,983 per QALY. ${ }^{45}$ In sensitivity analyses, Kahn et al. found that the price of prevention was an important cost driver. For example, to achieve a $\$ 20,000$ cost per QALY for LDL-C reduction in low-risk individuals and blood pressure reduction in nondiabetic individuals would require annual treatment costs of $\$ 257$ and $\$ 622$, respectively. ${ }^{45}$

Cost-effectiveness evaluations of frequently used preventive screenings and treatments, based on quantitative assessments of expected outcomes in low- and high-risk groups, provide information intended to help payers and providers manage limited resources. Yet, these assessments are likely to generate ever-increasing controversy, especially among those deemed "low risk." For example, the U.S. Preventive Services Task Force (USPSTF) in November 2009 issued a new clinical guideline for the use of mammography, noting that based on "the number [of screenings] needed to save 1 life ... there is moderate evidence that the net benefit is small for women aged 40 to 49 years." ${ }^{46}$ Based in part on a decision analytic model of "the expected health outcomes and resource requirements of starting and ending mammography screening at different ages and using annual versus biennial screening intervals," the USPSTF recommended against routine screening mammography in women aged 40 to 49 years and called for only biennial mammograms for women aged 50 to 74 years. Notably, the USPSTF guidance conflicts with that of the American Cancer Society, which recommends annual mammography for women aged 40 years or older, and the American College of Obstetrics and Gynecology, which recommends mammography every 1 to 2 years for women aged 40 to 49 years and annually thereafter. ${ }^{46}$

\section{No Free Lunch-The Importance of Realistic Expectations}

"Harry and Louise" are back-this time in a campaign cosponsored by the Pharmaceutical Research and Manufacturers of American (PhRMA) and Families USA, a universal coverage advocacy group. ${ }^{31}$ "A little more cooperation, a little less politics," says Louise, "and we can get the job done this time." 31 A campaign of this nature suggests that fundamental questions about how such a system would work-and especially how it would avoid the obstacles that have plagued other large-scale systemic implementations that sought simultaneously to reduce costs and expand eligibility-have been answered. In fact, these critical questions remain essentially unaddressed. Is it possible to have a health care system that offers both expanded coverage and lower costs? The answer seems to be perhaps, but not without substantial tradeoffs.

First, those who would point to systems in other countries as indicators of "silver bullet" solutions for the United States should note that those other systems commonly rely on features that many Americans would find unacceptable (Table 1).47,48 For example, in France and the United Kingdom, the frequency of physician office visits per capita is much higher than in the United States, but physician remuneration is lower, estimated at $\$ 55,000$ annually in France versus $\$ 194,000$ in the United States 


\section{TABLE 1 Comparisons of the United States, France, and the United Kingdom on Selected Health Indicators}

\begin{tabular}{|c|c|c|c|}
\hline & United States (\%) & France (\%) & United Kingdom (\%) \\
\hline \multicolumn{4}{|l|}{ Nonmedical factors $^{a}$} \\
\hline Adults with BMI $>30 \mathrm{~kg} / \mathrm{m}^{2}$ & 32.2 & 9.5 & 23.0 \\
\hline Adults who smoke daily & 16.9 & 23.0 & 24.0 \\
\hline \multicolumn{4}{|l|}{ Mortality rates per 100,000 population ${ }^{\mathrm{b}}$} \\
\hline Ischemic heart disease (males) & 170.3 & 64.2 & 153.6 \\
\hline Stroke (males) & 41.4 & 41.1 & 58.3 \\
\hline Cancer (all cancers, males and females) & 203 & 244 & 214 \\
\hline Breast cancer (females) & 22.0 & 23.5 & 26.0 \\
\hline Prostate cancer (males) & 20.5 & 24.8 & 26.1 \\
\hline Lung cancer (males and females) & 65 & 59 & 52 \\
\hline \multicolumn{4}{|l|}{ Service utilization and equipment availability ${ }^{c}$} \\
\hline Physician consultations per capita & 3.8 & 6.6 & 5.1 \\
\hline Coronary revascularization procedures per 100,000 & 579 in 2004 & 196 in 2001 & 169 in 2004 \\
\hline Patients treated for end-stage renal failure per 100,000 & 161 & not reported & 63 \\
\hline Patients undergoing dialysis per 100,000 & 114 & not reported & 35 \\
\hline MRI units per 1 million population & 26.6 & 4.7 & 5.4 \\
\hline CT scanners per 1 million population & 32.2 & 9.8 & 7.5 \\
\hline \multicolumn{4}{|l|}{ Reimbursement of health care professionals ${ }^{\mathrm{d}}$} \\
\hline Ratio of physicians' remuneration to GDP per capita & 6.5 in 2001 & 5.0 in 2004 & 4.8 in 2004 \\
\hline Ratio of hospital nurses' remuneration to GDP per capita & 1.5 in 2004 & not reported & 1.3 in 2004 \\
\hline Cancer screening ${ }^{\mathrm{e}}$ & United States & France & Western Europe \\
\hline \multicolumn{4}{|l|}{ Mammography in past 2 years } \\
\hline Women aged 50-64 years & 77.3 & 63.0 & 46.2 \\
\hline Women aged $65-74$ years & 74.1 & 49.7 & 32.6 \\
\hline Women aged 75 years or older & 58.5 & 16.3 & 12.7 \\
\hline \multicolumn{4}{|c|}{ Colorectal cancer screening tests in past 5 years in United States, past 10 years in Europe } \\
\hline Aged $50-64$ years & 45.1 & 27.4 & 22.2 \\
\hline Aged $65-74$ years & 60.6 & 31.2 & 25.9 \\
\hline Aged 75 years or older & 52.6 & 16.6 & 18.3 \\
\hline \multicolumn{4}{|l|}{ Pap smear in past year } \\
\hline Women aged 50-64 years & 55.5 & 59.9 & 48.9 \\
\hline Women aged $65-74$ years & 42.1 & 26.7 & 28.2 \\
\hline Women aged 75 years or older & 21.9 & 7.4 & 12.0 \\
\hline \multicolumn{4}{|l|}{ PSA test in past year } \\
\hline Men aged 50-64 years & 42.2 & 36.8 & 27.1 \\
\hline Men aged 65-74 years & 61.5 & 50.8 & 35.8 \\
\hline Men aged 75 years or older & 57.9 & 28.1 & 32.6 \\
\hline
\end{tabular}

aOECD, data for 2004 and 2005.47

bOECD. All data are age-adjusted. U.S. data are 2002, French data are 2003, and United Kingdom data are 2004.47

${ }^{c} O E C D$. Although hospital discharges per 1,000 are reported by OECD, the data for the United States exclude healthy newborn discharges and are therefore not comparable to data for France and the United Kingdom. ${ }^{47}$ Except where otherwise noted, data are for 2005 or latest year available.

${ }^{d}$ French and U.S. data reflect self-employed physicians; United Kingdom data represent salaried physicians. For salaried physicians in the United States, the result was $4.8 .{ }^{47}$

eU.S. screening rates were obtained from 2004 Medical Expenditure Panel Survey. European data were obtained from the 2004 Survey of Health, Ageing, and Retirement in Europe and the 2006 Eurobarometer Survey. ${ }^{48}$ Data for the United Kingdom were not available.

$B M I=$ body mass index; $C T=$ computerized axial tomography; $G D P=$ gross domestic product; $\mathrm{kg} / \mathrm{m}^{2}=$ kilograms per squared meter; $M R I=$ magnetic resonance imaging; $O E C D=$ Organisation for Economic Co-Operation and Development; PSA = prostate-specific antigen.

in 2003..$^{47-49}$ In the United States, where one can see harbingers of restrictions on provider reimbursement in the renewed interest in prepayment per episode or month as a financial mechanism, it is reasonable to question whether American physicians would accept a pay cut of this magnitude. Although it is difficult to make international comparisons because of other system-wide differences (e.g., malpractice, medical school system), it is known that labor tensions are common among French physicians. ${ }^{49}$ Similarly, whether physicians in Massachusetts will accept payment methodologies designed to reduce their income is even more questionable, especially since the state is currently experiencing a "critical shortage of primary care physicians," according 
to the Rand report. ${ }^{25}$ It is also reasonable to question whether Americans, especially older Americans, would accept the features that characterize health care systems in European countries, such as lower cancer screening rates; lower use rates and availability for high-technology medical services, such as dialysis, magnetic resonance imaging and computerized axial tomography; and markedly declining cancer screening rates with increasing age (Table 1). ${ }^{47,48}$

Second, the notion that universal coverage will reduce health care costs by increasing population health-both because of an influx of healthier individuals into the covered enrollee pool and because use of preventive care will save money by reducing rates of serious illness and complications-is popular but refuted both by evidence and by experience with previous coverage expansions. The Rand HIE, the only randomized study of the relationship between cost-sharing, health utilization, and health outcomes, found that families assigned to the experiment's "stingiest" plan (a \$1,000 annual deductible in 1975-1981 dollars), used approximately one-third fewer health care services than those whose health care was provided free of charge. Rand HIE researchers noted with concern that cost-sharing participants reduced both the use of "essential" and "nonessential" services by approximately equal amounts. However, over a study period of 3 to 5 years, the additional medical service use in the free-care group was associated with almost no improvements in health outcomes, although the free-care group used more preventive screening services, including pap smears, breast, and rectal exams. ${ }^{43,50}$ Although free care did produce slightly better blood pressure detection and control (mean diastolic blood pressure difference of 3 millimeters mercury), and better vision and dental outcomes among low-income participants, free-care participants had 2 more restricted activity days per year than those in costsharing plans, "perhaps because of the extra time spent in visiting the doctor." ${ }^{\text {"43 }}$

Given the findings of the Rand HIE, the U.S. experience that large-scale health insurance coverage expansions produce large increases in health care expenditures is predictable. It is both sobering and instructive that those spending increases have significantly threatened the financial sustainability of U.S. systems that have attempted such coverage expansions.

Third, although Americans naturally favor systems that give them choice, the combination of universal coverage and completely unfettered access to treatment is financially unsustainable at current market prices for drugs and providers. In Massachusetts, which is known for the availability of cutting-edge medical technology, whether consumers will accept the change to prepaid arrangements without fear of profit-motivated denials of care is an empirical question. Yet the prepaid reimbursement methods proposed in Massachusetts, intended to reduce utilization, have been deemed essential for the near-universal coverage system to survive. To be both financially sustainable and accepted by the American public, a health care system must either provide enrollees with the right to choose any provider and treatment for which they are willing to bear some financial responsibility, or successfully convince enrollees that giving up some freedom of choice is important for the long-term viability of the health plan.

It would also be reasonable, and perhaps wise, to educate consumers that cost containment measures may have clinical benefits. For example, incentives to use generic medications have the effect of directing patients to older products with which there is more safety experience, as recent evidence of the adverse event risks associated with newer oral antidiabetic medications bears out. ${ }^{51}$ Consumers and decision makers might also heed the lessons learned from more than 20 years of dedicated and passionate pursuit of quality improvements at Intermountain Health Care (IHC), an integrated health system based in Salt Lake City, Utah. Embracing since the 1980s a corporate culture of continuous quality improvement, including statistical analyses of health care outcomes and application of management theory to health system administration, IHC has incrementally improved the quality of medical care. ${ }^{52}$ The reported results of IHC's intense efforts-including reductions in adverse drug reactions, preterm deliveries and neonatal intensive care use, and readmission rates for costly conditions like heart failure and pneumonia-have the potential to enhance patient satisfaction, improve outcomes, and reduce costs. However, physician resistance to "evidencebased" statistical analysis is common, and success is considered more likely among salaried than fee-for-service physicians. Additionally, systems like IHC's take time to develop. As one physician observer noted, IHC's system "is the future ... But how long are you willing to wait? It may take 100 years." ${ }^{2}$

Fourth, the potential for unintended consequences in any redesigned system is large. As former administrator of the Health Care Financing Administration (now CMS) Gail Wilensky observed in a commentary on the health care reform proposals being considered in 1994, the history of governmental financing of major health initiatives is replete with erroneous financial calculations and predictions about how people and organizations would respond to new incentives. ${ }^{53}$ The experiences with TennCare and universal coverage in Massachusetts support this view. The $\mathrm{CBO}$ has observed that the country's difficulty reaching consensus about reform is partly attributable to "lack of evidence about the likely impact of making significant changes to the complex system of health insurance and health care."'24

\section{Are We Learning From History or Destined to Repeat It?}

Advocating for particular policies in a highly fluid debate is difficult. The important topics of insurance regulation and tax policy, which play a major role in the current debate, are beyond the scope of this editorial. Increased use of electronic medical records (EMRs), frequently touted as a measure that could greatly offset the cost of coverage expansions, is also not covered here; evidence suggests that the potential cost offsets are minimal. ${ }^{54}$

Historical experience with public opinion and public response 
to universal coverage provides important information about how to balance choice versus cost. The general approach suggested jointly by former Clinton advisor Ira Magaziner and former Speaker of the House Newt Gingrich in an interview with Health Affairs in 2000 seems sensible. ${ }^{55}$ Magaziner called for a system that "provides some national pool at a catastrophic level and then provides a discretionary pool for everyday expenditures that gives people an incentive to manage their health spending more carefully." Magaziner added that to "ensure that people seek appropriate preventive care, certain tests and immunizations might be covered from the national pool as well." ${ }^{25}$ Such an approach recognizes that American health care consumers want choices, mitigating the problem of backlash against coverage decisions that are perceived to be motivated by profit, while providing coverage for catastrophic expenses. At the same time, by "introducing more personal responsibility ... for the spending of the everyday health care dollar," 55 as Magaziner points out, it provides a reasonable and choice-based mechanism for cost containment consistent with the results of the Rand HIE and the findings of quasi-experimental research that moderate cost sharing is associated with no adverse effects..$^{56}$

No matter what path is taken, it is clear that difficult tradeoffs will be necessary. As the $\mathrm{CBO}$ has observed, a "substantial share of spending on health care contributes little if anything to the overall health of the nation, but finding ways to reduce such spending without also affecting services that improve health will be difficult ... Given the central role of medical technology in cost growth, reducing or slowing spending over the long term would probably require decreasing the pace of adopting new treatments and procedures or limiting the breadth of their application."24 Yet, history suggests that when Americans experience externally imposed limits on their access to those treatments and procedures, the result is rebellion.

\section{Authors}

KATHLEEN A. FAIRMAN, MA, is Associate Editor and Senior Methodology Reviewer, and FREDERIC R. CURTISS, PhD, RPh, CEBS, is Editor-in-Chief, Journal of Managed Care Pharmacy.

AUTHOR CORRESPONDENCE: Kathleen A. Fairman, MA, Kathleen Fairman LTD, P.O. Box 31278, Phoenix, AZ 85046. Tel.: 602.867.1343; E-mail: kfairman@amcp.org.

\section{DISCLOSURES}

The authors have no conflicts of interest related to the subjects or products discussed in this article.

\section{REFERENCES}

1. Eckholm E. Late starter in Medicaid, Arizona shows the way. NY Times. August 7, 1991. Available at: http://www.nytimes.com/1991/08/07/us/latestarter-in-medicaid-arizona-shows-the-way.html?pagewanted=all. Accessed November 7, 2009.

2. Gleick E, Cohen A, Willwerth J. A tale of two states. Time. December 18, 1995. Available at: http://www.time.com/time/magazine/article/0,9171,983845,00.html. Accessed November 7, 2009

3. Public Broadcasting System. Online forum. A detailed timeline of the healthcare debate portrayed in "The System." Available at: http://www. pbs.org/newshour/forum/may96/background/health_debate_pagel.html. Accessed November 17, 2009.

4. Heinz M. AHCCCS a model for nation. Arizona Republic. September 19, 2009. Available at: http://www.azcentral.com/arizonarepublic/opinions/articl es/2009/09/18/20090918heinz19.html. Accessed November 13, 2009.

5. McCall N. Lessons from Arizona's Medicaid managed care program. Health Aff (Millwood). 1997;16(4):194-99. Available at: http://content.healthaffairs.org/cgi/reprint/16/4/194.pdf. Accessed November 7, 2009.

6. McCall N, Wrightston CW, Paringer L, Trapnell G. Managed Medicaid cost savings: the Arizona experience. Health Aff (Millwood). 1994;13(2):23445. Available at: http://content.healthaffairs.org/cgi/reprint/13/2/234. Accessed November 17, 2009.

7. McCall N, Jay ED, West R. Access and satisfaction in the Arizona Health Care Cost Containment System. Health Care Financ Rev. 1989;11(1):63-77.

8. Chang CF. Evolution of TennCare yields valuable lessons. Manag Care. 2007;16(11):45-49. Available at: http://www.managedcaremag.com/ archives/0711/0711.peer_tenncare.pdf. Accessed November 10, 2009

9. Chang CF, Steinberg SC. TennCare timeline: major events and milestones from 1991 to 2009. January 2009. Available at: http://healthecon.memphis.edu/Documents/TennCare/TennCare_Bulleted_Timeline_Chang.pdf. Accessed November 11, 2009.

10. Mirvis DM, Chang CF, Hall CJ, Zaar GT, Applegate WB. TennCarehealth system reform for Tennessee. JAMA. 1995;274(15):1235-41. Available at: http://jama.ama-assn.org/cgi/reprint/274/15/1235. Accessed November 9, 2009.

11. Anonymous. HillaryCare in Tennessee: the disaster that might have been for the entire country. Wall Street J. December 6, 2004. Available at: http:// www.opinionjournal.com/editorial/feature.html?id=110005987. Accessed November 11, 2009.

12. Iglehart JK. Managed competition. N Engl J Med. 1993;328(16):1208-12.

13. Froomkin D. Backlash builds over managed care. Washington Post. February 23, 1999. Available at: http://www.washingtonpost.com/wp-srv/ health/policy/managedcare/overview.htm. Accessed November 12, 2009.

14. Blendon RJ, Brodie M, Benson JM, et al. Understanding the managed care backlash. Health Aff (Millwood). 1998;17(4):80-94.

15. Eckholm E. $\$ 89$ million awarded family who sued HMO. NY Times. December 30, 1993. Available at: http://www.nytimes.com/1993/12/30/ us/89-million-awarded-family-who-sued-hmo.html. Accessed November 12, 2009.

16. Gratzer D. What ails health care. The Public Interest. March 21, 2005. Available at: http://www.manhattan-institute.org/pdf/PI_gratzer_spring05. pdf. Accessed November 12, 2009.

17. Miller RH, Luft HS. Managed care plan performance since 1980: a literature analysis. JAMA. 1994;271(19):1512-19.

18. Lane C. A "flip-flop" on patients' right to sue? Washington Post. April 5, 2004. Available at: http://www.washingtonpost.com/ac2/wp-dyn/A501632004Apr4?language=printer. Accessed November 12, 2009.

19. The Internet Movie Database. John $Q$ plot summary. Available at: http:// www.imdb.com/title/tt0251160/plotsummary. Accessed November 16, 2009 
20. Mirvis DM, Bailey JE, Chang CF. TennCare-Medicaid managed care in Tennessee in jeopardy. Am J Manag Care. 2002;8(1):57-68. Available at: http://www.ajmc.com/media/pdf/AJMC2002jan_MIRVIS57_68.pdf. Accessed November 17, 2009.

21. State of Tennessee. Latest news: state moves toward Medicaid. November 10, 2004. Available at: http://www.tennesseeanytime.org/governor/viewArticleContent.do?id=7\&page=0. Accessed November 11, 2009.

22. Tennessee Justice Center. TennCare. Available at: http://www.tnjustice. org/tenncare/default.htm. Accessed November 11, 2009.

23. Gold M, Aizer A. Growing an industry: how managed is TennCare's managed care? Health Aff (Millwood). 2000;19(1):86-101. Available at: http:// content.healthaffairs.org/cgi/reprint/19/1/86. Accessed November 11, 2009.

24. Elmendorf DW. Expanding health insurance coverage and controlling costs for health care. Testimony before the Committee on Budget, United States Senate. Congressional Budget Office. February 10, 2009. Available at: http://www.cbo.gov/ftpdocs/99xx/doc9982/02-10-HealthVolumes_ Testimony.pdf. Accessed November 9, 2009.

25. Eibner CE, Hussey PS, Ridgely MS, McGlynn EA. Controlling health care spending in Massachusetts: an analysis of options. Rand Health. August 2009. Available at: http://www.rand.org/pubs/technical_reports/2009/ RAND_TR733.pdf. Accessed November 9, 2009.

26. Weissman JS, Bigby J. Massachusetts health care reform-near-universal coverage at what cost? N Engl J Med. 2009 Oct 21. [Epub ahead of print].

27. Tanner M. Massachusetts miracle or Massachusetts miserable: what the failure of the 'Massachusetts model' tells us about health care reform. Cato Institute Briefing Papers. June 2009. Available at: http://www.cato.org/pubs/ bp/bp112.pdf. Accessed November 9, 2009.

28. News-Medical. Massachusetts health insurance law could cost more than anticipated. January 23, 2007. Available at: http://www.news-medical. net/news/2007/01/23/21481.aspx. Accessed November 10, 2009.

29. Commonwealth of Massachusetts. Recommendations of the Special Commission on the Health Care Payment System. July 16, 2009. Available at: http://www.mass.gov/Eeohhs2/docs/dhcfp/pc/Final_Report/Final_ Report.pdf. Accessed November 9, 2009.

30. Kowalczyk L. Pay for care a new way, state is urged. Boston Globe. July 17, 2009. Available at: http://www.boston.com/news/local/massachusetts/ articles/2009/07/17/pay_for_care_a_new_way_state_is_urged/?page $=1$. Accessed November 19, 2009.

31. Fuhrmans V. Harry and Louise are back. Again. Wall Street J. July 16, 2009. Available at: http://blogs.wsj.com/health/2009/07/16/harry-and-louiseare-back-again/. Accessed November 12, 2009.

32. Goldsteen RL, Goldsteen K, Swan JH, Clemena W. Harry and Louise and health care reform: romancing public opinion. J Health Polit Policy Law. 2001;26(6):1325-52.

33. Singer N. Harry and Louise return, with a new message. NY Times. July 16, 2009. Available at: http://www.nytimes.com/2009/07/17/business/ media/17adco.html?_r=1\&pagewanted=print. Accessed November 12, 2009.

34. Goldstein J. As Washington ponders health reform, Harry and Louise return. Wall Street J. August 19, 2008. Available at: http://blogs.wsj.com/ health/2008/08/19/as-washington-ponders-health-care-reform-harry-andlouise-return/. Accessed November 11, 2009.

35. Tennessee Justice Center. Grier v. Goetz. Available at: http://www.tnjustice.org/case/grier/default.htm. Accessed November 10, 2009.

36. Tennessee Justice Center. Myth \#5. Available at: http://www.tnjustice. org/tenncare/myths/myth_5.html. Accessed November 11, 2009.

37. Lane M. Leave prescriptions to doctors. Arizona Republic. September 15, 2009. Available at: http://www.azcentral.com/arizonarepublic/opinions/articl es/2009/09/14/20090914lanel5.html. Accessed November 9, 2009.
38. Fairman KA, Curtiss FR. The elephant in the pharmacy: patient choice is the big challenge that no one talks about in affordability of prescription drugs. J Manag Care Pharm. 2007;13(7):620-22. Available at: http:// www.amcp.org/data/jmcp/JMCPMaga_Sept\%2007_620-622.pdf. Accessed November 12, 2009.

39. Trust for America's Health. New health care vs. sick care ad campaign launched by Trust for America's Health and Partnership for Prevention. October 28, 2009. Available at: http://healthyamericans.org/newsroom/ releases/?releaseid=196. Accessed November 13, 2009.

40. Trust for America's Health. Prevention for a healthier America: investments in disease prevention yield significant savings, stronger communities. February 2009. Available at: http://healthyamericans.org/reports/prevention08/Prevention08.pdf. Accessed November 14, 2009.

41. Trust for America's Health. Blueprint for a healthier America: modernizing the federal public health system to focus on prevention and preparedness. October 2008. Available at: http://healthyamericans.org/assets/files/ Blueprint.pdf. Accessed November 14, 2009.

42. Baucus M, Kennedy EM. We cannot delay health-care reform. Wall Street J. February 26, 2009. Available at: http://online.wsj.com/article/ SB123560875690877203.html. Accessed November 14, 2009.

43. Keeler EB. Effects of cost sharing on use of medical services and health Summer 1992. Rand Health. Available at: http://www.rand.org/pubs/ reprints/2005/RP1114.pdf. Accessed November 14, 2009.

44. Cohen JT, Neumann PJ, Weinstein MC. Does preventive care save money? Health economics and the presidential candidates. N Engl J Med. 2008;358(7):661-63.

45. Kahn R, Robertson RM, Smith R, Eddy D. The impact of prevention on reducing the burden of cardiovascular disease. Diabetes Care. 2008;31(8):1686-96. Available at: http://care.diabetesjournals.org/content/31/8/1686.long. Accessed November 15, 2009.

46. U.S. Preventive Services Task Force. Screening for breast cancer: U.S. Preventive Services Task Force Recommendation Statement. Ann Intern Med. 2009;151(10):716-26. Available at: http://www.ahrq.gov/clinic/uspstf09/ breastcancer/brcanrs.pdf. Accessed November 17, 2009.

47. Organisation for Economic Co-Operation and Development. Health at a Glance 2007: OECD Indicators. OECDpublishing. November 13, 2007.

48. Howard DH, Richardson LC, Thorpe KE. Cancer screening and age in the United States and Europe. Health Aff (Millwood). 2009;28(6):1838-47.

49. Rodwin VG. The health care system under French National Health Insurance: lessons for health reform in the United States. Am J Pub Health. 2003;93(1):31-37.

50. Brook RH, Ware JE, Rogers WH, et al. Does free care improve adults' health? Results from a randomized controlled trial. N Engl J Med. 1983;309(23):1426-34.

51. Curtiss FR, Fairman KA. Diabetes drug therapy—first, do no harm. J Manag Care Pharm. 2008;14(7):658-60. Available at: http://www.amcp.org/ data/jmcp/658-660_CurtissFairman-Final.pdf. Accessed November 15, 2009.

52. Leonhardt D. Making health care better. NY Times. November 8, 2009. Available at: http://www.nytimes.com/2009/11/08/magazine/08Healthcare-t. html?pagewanted=2\&_r=2\&th\&emc=th. Accessed November 17, 2009.

53. Wilensky GR. Health reform: what will it take to pass? Health Aff (Millwood). 1994;13(1):179-91.

54. Groopman J, Hartzband P. Obama's $\$ 80$ billion exaggeration. Wall Street J. March 12, 2009. Available at: http://online.wsj.com/article/ SB123681586452302125.html\#printMode. Accessed November 17, 2009.

55. Gingrich N, Magaziner I. Two old hands and the new new thing: interview by Rob Cunningham. Health Aff (Millwood). 2000;19(6):33-40.

56. Fairman KA. The future of prescription drug cost sharing: real progress or dropped opportunity? J Manag Care Pharm. 2008;14(1):70-82. Available at: http://www.amcp.org/data/jmcp/JMCPMaga_JanFeb\%2008_070-082.pdf. 